\title{
Isolation, Identification and Molecular Characterization of Cadmium Resistant Bacteria Isolated from Polluted Drainage Water
} Ashgan A. Abougabal ${ }^{1}$, Ranya Amer ${ }^{2}$, Ahmed Abdel -Megeed ${ }^{3}$ and Magda Hider ${ }^{1}$

\begin{abstract}
Water is the most basic element for the life on earth. Reliable access to cleanly and affordable water is considered main challenge for the total world. Along with waste water progress, environmental pollutants like toxic heavy metals are widely spreading throughout the world. The presence of heavy metal in aqueous environment poses a dangerous environmental risk. The utilization of heavy metal resistance bacteria might avail a cost-efficient tool for bioremediations of contaminated water bodies. During our screening program for heavy metal resistant bacteria isolated from agriculture wastewater sample collected from mainsheet El Awqaf near kafr el-Dewar), ELBahaira Egypt was able to grow on (LB) medium supplemented with Cadmium (50 to $500 \mathrm{mg} / \mathrm{l})$,six isolates were chosen (4(DB-3), 5(DB-3), 6CB-3), 7(CB-7), J (CB-5), and $M(C B-3)$ based on the metal tolerance concentration (MIC) values these isolates were gram negative rod shaped bacteria.
\end{abstract}

Key words: Wastewater, Isolation, identification, Heavy metal removal, Cadmium, minimum tolerance concentrations, bioremediations.

\section{INTRODUCTION}

Water is amajor vital natural resource and crucial for permanence of all living organisms(WHO, 2012).The deficiency of renewable water resources, growing contradiction between demand and supply of clean water is a major challenge (Rijsberman, 2006). The competition for fresh-water allocation already exists among domestic, industrial and agricultural sectors, especially in water rare areas (Qadir et al., 2010). In some countries, irrigation accounts for further than $95 \%$ of the developed water supply (AQUASTAT, 2012). The expanding shortage of water joined with different factors is driving a large number of agriculturists to make utilization of wastewater.

Wastewater is being utilized for water system on an expected 4.5 million hectares around the world(Jiménez and Asano, 2008).Other scientists estimated around 200 million farmers use irrigate with treated and untreated polluted water in irrigation (Sato et al., 2013). More than 20 million hectares of ground are now irrigated with polluted water, The problem is that a greater percentage of this practice is not based on any scientific management that ensures the "safe use" of polluted water(Hettiarachchi and Ardakanian, 2016).

Egypt, an arid country in the end of the longest river in the world, has passive water balance. The Egyptian share of the River Nile has been constant since the treaty of 1959, while the population has increased around three times during the same period (Hettiarachchi and Ardakanian, 2016). The annual supply of water from the Nile water, rainfall along the Mediterranean Coast and profound groundwater amounts to equal 57.7 billion cubic meters. But every year, Egypt employs around 72.4 billion cubic meters of water how is it possible for a country to use $25 \%$ more water than it has. Much of Egypt's water is use multiplied times on its journey through the country. Reuse increased overall efficiency from $57 \%$ to $74 \%$. Other references estimated that overall irrigation efficiency increased from below $50 \%$ to $82 \%$ with the effect of reuse (Oosterbaan, 1999). The unofficial use of drainage water by farmers is about 3.0 BCM/year and is rising rapidly with the increase in water crises Allam (2001) In the future, irrigating agricultural area with this wastewater or treated polluted water could be a popular scenario in the developing countries because of the nonavailability of clean fresh water (Raja et al., 2015). The water applied for agriculture in 2025 will be 1.4 times that of 2000, i.e., $82 \mathrm{BCM}$ and $34.8 \mathrm{BCM}$ returns to the system (Aboulroos and Satoh 2017). Final losses are 18.7 BCM, including 2.8 BCM that are evaporated and 15.9 $\mathrm{BCM}$ from the drainage water that are dumped to the sea, and the rest is reused (Hettiarachchi, et al., 2016).

Heavy metals wastewater are directly or indirectly thrown into the environment progressively; especially in developing countries (Khalil et al., 2016). Heavy-metals have a crucial role in the metabolic operation of the biota, some of them are essential for all organisms as micro nutrients (cobalt, chromium, nickel, iron, manganese and zinc. However, at high levels, both of the major and non-essential metals become poisonous to

\footnotetext{
${ }^{1}$ Department of Agricultural Plants, Faculty of Agriculture Saba Basha and Alexandria University

${ }^{2}$ Environmental Biotechnology Dept., GEBRI, City for Scientific

Research and Technology Applications SRTA City.

${ }^{3}$ Department of Plant Protection, Faculty of Agriculture Saba

Basha and Alexandria University

* Corresponding author: e-mail: gene_m2014@yahoo.com

Received May 27, 2018, Accepted June 28, 2018
} 
the organisms (Rathnayake et al., 2010) because they are toxic, non biodegradable in the environment, and facilely accumulated in living organisms(Coelho et al., 2015).

Cadmium is one hazardous heavy metal which non degradable easily, and has the capacity to accumulate in living organisms, causes significant problems to both the environment and public health (Zhai et al., 2015). it has been classified by the International Agency for Research on Cancer as a Category I human carcinogen .Cadmium can impact the kidney, occasion renal dysfunction and with increased exposure, the respiratory distress increases with uncontrollable cough and gastrointestinal pain, nausea, vomiting and diarrhea (Khojastehfar et al., 2015).

The conventional physicochemical technologies appear to be inadequate or high cost for removal heavy metals at lower concentrations New approaches are continually being examined to supplement traditional water treatment methods (Marin-Morales et al., 2016). There are a bio materials used to remove heavy metal from polluted water, such molds, yeasts, bacteria, and seaweeds (Yaseen et al.,2018; El-Refaey, 2016; El-Aziz et al., 2016). Several studies shown that many organisms (prokaryotes and eukaryotes) have a naturalistic capacity to biosorb toxic metal ions (Kharwar et al., 2017). The aim of this work deals with the evaluation of the level of contamination of wastewater bodies, the isolation of heavy metals resistant bacteria in terms of $\mathrm{Cd}$ resistance, morphological characteristics and their potential capacity to MIC .

\section{MATERIALS AND METHODS}

\section{Sample collection:}

Waste water samples were collected from an agricultural drain at mainsheet El Awqaf near kafr elDewar (latitude 31.13566 North and longitude 30.13278 East), EL-Bahaira, Egypt in August 2016. Samples were packed in sterile glass bottles and stored at $4^{\circ} \mathrm{C}$ until transport to the laboratory for microbiological and further analysis.

\section{Physicochemical Characteristics for Water Samples:}

The physicochemical parameters were analysis by measuring elemental of $\mathrm{Cu}, \mathrm{Cd}, \mathrm{fe}, \mathrm{Mn}$ and $\mathrm{pb}$ were examined for agricultural drainage water samples using Atomic Adsorption Spectrophotometer (analyticjena,contrAA700) in faculty of agriculture saba-basha, Alexandria, Egypt as shown in Table1 then transferred samples to Sotic Group Company to measure pesticides by GC-MS.

\section{Isolation of Bacterial strains}

Isolation and enumeration of the bacterial populations was based on serial dilution technique (Banerjee et al., 2015; Kang and Kondo, 2002; Khatiwada et al., 2016)with a little modification $1 \mathrm{~mL}$ of waste water samples were suspended in $9 \mathrm{ml}$ of sterile distilled water) and serially diluted to $10^{-9}$ with distilled water. Then, $0.1 \mathrm{ml}$ of diluted suspension was placed on Luria bertani (Peptone $10.00 \mathrm{~g} / \mathrm{L}$, yeast extract, 5.00 $\mathrm{g} / \mathrm{L}, \mathrm{NaCl} 10.00 \mathrm{~g} / \mathrm{L}$ and agar $20.00 \mathrm{~g} / \mathrm{L}: \mathrm{pH} 7.00$ ) agar plates. After that the plates incubated at 30 ? for 24 hours then isolates colonies picked out, cultured for purification and identification. For long-term preservation and maintenance, the microbial cultures were stored as $60 \%$ glycerol stocks in Eppendorff tubes, mixed well and stored at -20 ?C.

\section{Identification of the Selected Resistant Isolate Morphological Characteristics}

Morphological characteristics namely, colony morphology (color and shape) cell morphology (shape and gram reaction) of the chose isolate were studied (Holt et al., 1994).

\section{Primary screening of heavy metal resistant bacteria}

For the selective screening of heavy metal resistant bacteria, 50-200 $\mathrm{mg} / \mathrm{L}$ of heavy metal (cadmium) incorporated (LB-broth) medium. The isolates were grown in a rotary shaker at $150 \mathrm{rpm}$ and $\mathrm{pH} 7.0$ and the temperature was $30^{\circ} \mathrm{C}$ After $24,48 \mathrm{~h}$ incubation sample was collected by taking $1 \mathrm{ml}$ of growth from this flask to read the density of this growth at $550 \mathrm{~nm}$ using spectrophotometrically (Bestawy et al., 2013). The highest metal concentration $175,200 \mathrm{mg} / \mathrm{l}$ the waste water activity was amended in Petri dish sterile LB agar. Control also prepared with LB media without including any heavy metal to make comparison, serial dilution was done as (Azad et al., 2013) to isolate desired bacteria. Colonies differing in morphological characteristics were selected, picked, purified and then preserved on different plates for further studies.

\section{Screening for Heavy Metal Resistant Bacteria \\ Determination of minimum inhibitory concentration (MIC) of the isolated microbial consortium}

The MIC of the cadmium metal ion was determined by turbid metric analysis. Bacterial isolates were cultured into shake flask and cultivated in LB broth medium broth in various concentrations ranging from $50-500 \mathrm{mg} / \mathrm{L}$. After incubation while $\mathrm{pH}$ and temperature were maintained 7.0 at $30^{\circ} \mathrm{C}$ for $24,48 \mathrm{~h}$ in a rotary shaker at $150 \mathrm{rpm}$, the optical density was measured at $550 \mathrm{~nm}$ to measure the turbidometric analysis culture using Spectrophotometer (Marzan et al.,2017; Rajeshkumar et al., 2012). 


\section{RERSULTS AND DISCUSSION}

Organization of the United Nations(Ayers and Westcot, 1994) and Egyptian standards(Gad and Ali, 2009; Physicochemical characteristics of waste water

Results revealed higher pollution load parameters of heavy metal in the waste water, several chemical elements were found at concentrations ranged between 0.25 to $49.9 \mathrm{mg} / \mathrm{l}$, Table 1 . The Atomic absorption spectrophotometric analysis of metals in water samples detected a high level of $\mathrm{Fe}, \mathrm{Mn}, \mathrm{Cu}, \mathrm{pb}$, and $\mathrm{Cd}$. Manganese was the highest (49.9ppm) in water samples followed by $\mathrm{Fe}(38.6 \mathrm{ppm}), \mathrm{Cu}(31.7 \mathrm{ppm}), \mathrm{Cd}$ (30.7ppm), and $\mathrm{Pb}(0.37 \mathrm{ppm})$. Cadmium was found only at Sample 2 concentration is $30.7 \mathrm{ppm}$ of water. The water characteristics were contrasted guidelines of the Food, Agriculture Nasr and Zahran, 2016).

Table1.Analysis of heavy metals in water samples

\begin{tabular}{cccc}
\hline $\begin{array}{c}\text { Heavy } \\
\text { metal (ppm) }\end{array}$ & Sample1 & Sample2 & Sample3 \\
\hline $\mathrm{Cd}$ & 0.8777 & 30.78 & 2.343 \\
$\mathrm{~Pb}$ & No result & 0.2560 & 0.3740 \\
$\mathrm{Cu}$ & 0.4241 & 31.75 & 0.3740 \\
$\mathrm{Fe}$ & 38.68 & 18.25 & 1.047 \\
$\mathrm{Mn}$ & 43.66 & 49.96 & 3.949 \\
\hline
\end{tabular}

In this study we recognize and describe of heavy metal tolerant bacteria isolated from drainage waste water. They were isolated from heavily polluted water and environments(Benidickson, 2011; El-Bestawy et al., 2008). Cultures were maintained at $4^{\circ} \mathrm{C}$ on nutrient agar slants and transferred monthly

\section{Pesticides analysis}

The waste water samples on subjecting to GC-MS provide result of different peaks determining the presence of different compounds. The molecular weight of these compounds is also known. The Chromatogram (Figure 1) shows 4prominent peaks in the retention time range $6.23-32.10$. GC-(sample 1), the retention time range 2.93-32.10(sample2) and the retention time range 3.12-33.94(sample3) MS analysis was done for the three waste water samples and 5,8 and 12 compounds were identified in sample 1,2 and 3 respectively. The GC-MS analysis of all waste water samples active principles with their retention time (RT), the Compound Name, Molecular Formula, Molecular weight (MW), Peak area\%, were presented in table 2.

\section{Phenotypic characterization of Bacteria}

Bacteria were examined for colony, cell morphology and gram staining. Cell varied between rods or cocci, only twelve isolates where spore former. Twenty eight isolates were gram positive, whereas nine were gram negative rod shaped bacterium. Compare with these characteristics of the standard description by (Holt et al., 1994), Table 3 shows that 21 isolates were found to be belonged to the family bacilli, 5 were found to be streptococcus Spp,3 staphylococci, one was found to be coccobacilli and

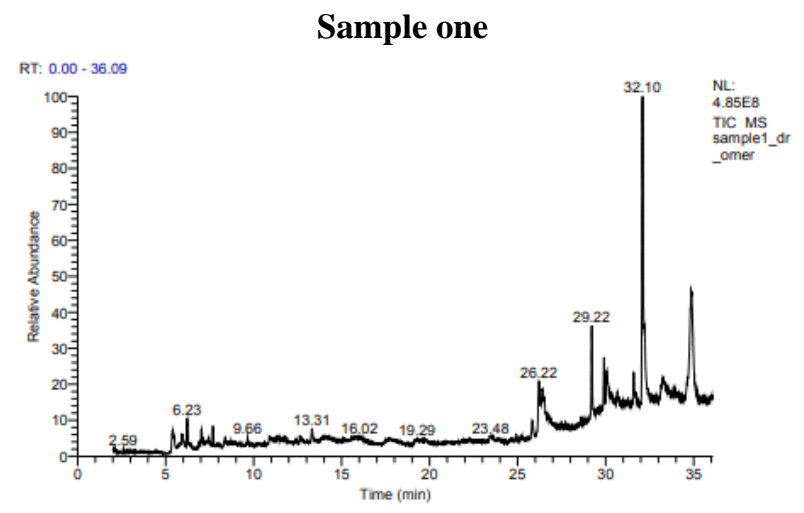

Figure 1.GC-MS Chromatogram of sample one, two and three from drainage water

Sample two

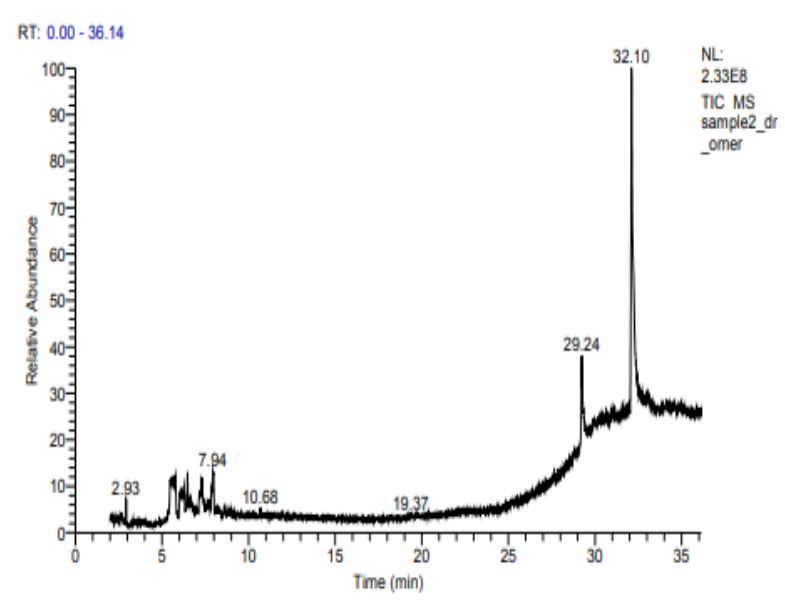

sample three

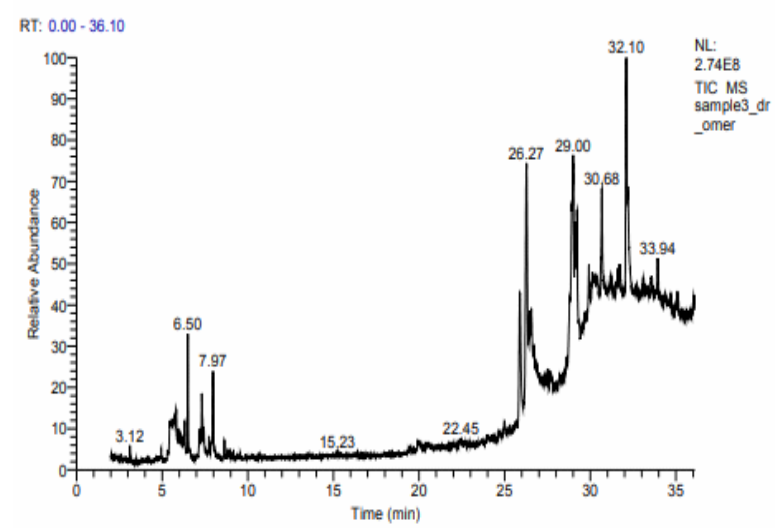

Figure 2.GC-MS Chromatogram of sample2 from drainage water 
Table2. GC-MS CHROMATOGRAM ANALYSIS OF waste water samples

Sample 1

\begin{tabular}{|c|c|c|c|c|c|}
\hline S.No & Retention .Time & The Compound name & $\begin{array}{l}\text { Molecular } \\
\text { Formula }\end{array}$ & MW & $\begin{array}{c}\text { Area } \\
\%\end{array}$ \\
\hline 1 & 6.23 & Ethanol,2-butoxy & C6H14O2 & 118 & 1.63 \\
\hline 2 & 26.22 & $\begin{array}{l}\text { 2(1H)-Benzocyclooctenone, } \\
\text { decahydro-40-methyl-,trans(-) }\end{array}$ & $\mathrm{C} 13 \mathrm{H} 36 \mathrm{O}$ & 194 & 4.15 \\
\hline 3 & 29.22 & $\begin{array}{c}\text { Hexadecanoic acid,methyl } \\
\text { ester(CAS) }\end{array}$ & $\mathrm{C} 17 \mathrm{H} 34 \mathrm{O} 2$ & 270 & 6.55 \\
\hline 4 & 32.10 & 11-Octadecenoic acid,methyl ester & $\mathrm{C} 19 \mathrm{H} 36 \mathrm{O} 2$ & 296 & 33.94 \\
\hline \multicolumn{6}{|l|}{ Sample2 } \\
\hline S.NO & $\begin{array}{l}\text { Retention } \\
\text {.Time }\end{array}$ & The Compound name & $\begin{array}{l}\text { Molecular } \\
\text { Formula }\end{array}$ & MW & Area\% \\
\hline 1 & 2.93 & $\begin{array}{l}\text { Pentanoic acid Propanol } \\
\text { Cyanogen chloride (CAS) }\end{array}$ & $\mathrm{C} 5 \mathrm{H} 10 \mathrm{O} 2$ & 102 & 0.77 \\
\hline 2 & 7.94 & Benzene,1,3,5-trimethyl(CAS) & C9H12 & 120 & 5.82 \\
\hline 3 & 29.24 & $\begin{array}{l}\text { Pentadecanoic acid ,14-methyl- } \\
\text {,methyl ester (CAS) }\end{array}$ & $\mathrm{C} 17 \mathrm{H} 34 \mathrm{O} 2$ & 270 & 8.21 \\
\hline 4 & 32.10 & $\begin{array}{c}\text { Trans-13-Octadecenoic acid } \\
\text {,methyl ester }\end{array}$ & С19H36O2 & 296 & 38.10 \\
\hline \multicolumn{6}{|l|}{ Sample3 } \\
\hline S.NO & Retention.Time & The Compound name & Molecular Formula & MW & Area \% \\
\hline 1 & 3.12 & Cyanogens chloride & CCIN & 61 & 0.24 \\
\hline 2 & 6.50 & Ethanol,2-butoxy & $\mathrm{C} 6 \mathrm{H} 14 \mathrm{O} 2$ & 118 & 2.95 \\
\hline 3 & 7.97 & $\begin{array}{c}\text {-Mesithylene } \\
\text {-Benzene,1-ethyl-3-methyl }\end{array}$ & C9H12 & 120 & 3.10 \\
\hline 4 & 26.27 & $\begin{array}{c}2(1 \mathrm{H})- \\
\text { Benzocyclooctenone,decahydro- } \\
\text { 4a-methyl-trans(-) } \\
\text { Tetrahydro-Ionone }\end{array}$ & $\mathrm{C} 13 \mathrm{H} 22 \mathrm{O}$ & 194 & 12.05 \\
\hline 5 & 29.00 & $\begin{array}{c}\text { Diisooctyl phthalate } \\
\text { 1,2-Benzenedicarboxylic acid,3- } \\
\text { nitro-(CAS) }\end{array}$ & $\mathrm{C} 24 \mathrm{H} 38 \mathrm{O} 4$ & 390 & 7.84 \\
\hline 6 & 30.68 & IsoCHIAPIN B & $\mathrm{C} 19 \mathrm{H} 22 \mathrm{O} 6$ & 346 & 4.50 \\
\hline 7 & 32.10 & $\begin{array}{l}\text { Trans-13-Octadecenoic acid } \\
\text {,metrhyl ester }\end{array}$ & $\mathrm{C} 19 \mathrm{H} 36 \mathrm{O} 2$ & 296 & 12.92 \\
\hline 8 & 33.94 & ISOCHIAPIN B & $\mathrm{C} 19 \mathrm{H} 22 \mathrm{O} 6$ & 346 & 2.13 \\
\hline
\end{tabular}

Table3. Enumeration of Cadmium resistant bacteria species Isolated from drainage water

\begin{tabular}{cccc}
\hline Isolate colonies & Gram positive(+ve) & Gram negative(-ve) & Total \\
\hline Bacilli sp & 12 & 9 & 21 \\
Streptobacilli & 5 & - & 5 \\
Staphylococcus & 3 & - & 3 \\
Cocci & 1 & - & 1 \\
Coccobacilli & 1 & - & 1 \\
Total & 22 & 9 & 31 \\
\hline
\end{tabular}

one was belonged to Dicocci.(Rajesh et al., 2014) studied biosorption of cadmium by a novel bacterium isolated from industry effluent and found three strains labelled as BVR 1, BVR 2 and BVR 3 gram negative rod shaped bacteria.
Screening MIC of resistant bacteria isolates on consortium OD

Minimum inhibitory concentration (MIC) for Cadmium element was studied from 50 to $500 \mathrm{mg} / \mathrm{L}$. It was found that six isolates showed the highest tolerance 
to cadmium. (Table 4) bacteria have metal obligatory abilities, and they are known to show resistance to heavy metals and their detoxification, Jamaluddin et al.,( 2012) Finally, the best isolates (4(DB-3), 5(DB-3), 6CB-3), 7(CB-7), J (CB-5), and $\mathrm{M}$ (CB-3))were selected depend on their maximum grade of resistance to cadmium for moreover studies, this result correspondence with that stated by (Utgikar et al., 2002) showed that, although cadmium is bacteriostatic at minimize concentrations, it can prevent the growth of the bacteria at maximize concentrations.

(Bhagat et al., 2016)demonstrated the use of heavy metal resistance bacteria which perhaps avail costeffective tool for remediate of waste water bodies. The waste water sample gathered from polluted sites of downstream, Yamuna River, Delhi. The enrichment of stagnant water sample collect guide to isolate bacteria that considered remediate to resistance high cadmium concentrations and fit to clutivate at 2000 and 3000 $\mu \mathrm{g} / \mathrm{ml}$ of cadmium ion in the liquid medium. The fractional amplification and 16S mRNA gene sequencer were resolved for sequences homology by employ BLAST $\mathrm{He}$ found that the fractional nucleotide sequences of sample 2(revealed 99\% similarity with Pantoea agglomerans JCM1) and of sample 8( Enterobacter asburiae JCM 6051).

All the six isolate exhibited tolerance to cadmium. The growth models suggest resistance development or adaptatability of bacteria to heavy metals in aquatic environment. Tolerance to Cadmium Salts and Metal Absorption by using Different Microorganism was studied by Marina (Gelmi et al., 1994) generally; the Gram-negative species (Pseudomonas aeruginosa, Proteus mirabilis, Escherichia coli, and Salmonella typhimurium) bacteria and one yeast (Candida albicans) evidence to be highly tolerance to $\mathrm{Cd}$ ions and accumulated high amounts of $\mathrm{Cd}$ through growth. Two strains of $\mathrm{P}$. aeruginosa appeared that a high degree of tolerance to $\mathrm{Cd}$ and were particularly efficient in removing the metal from solutions. The metal absorption for Gram-negative bacteria species were dosed dependent, however, for the Cd-resistant staphylococci it reach to a plateau, this results submit that microorganism represented a good scenario to study the interactions between heavy metals and living microorganisms.

Researchers has describe Pseudomonas aeruginosa KUCADMIUM1 show that biological elimination of cadmium in the level of 75 to $89 \%$ of total content (Sinha and Mukherjee, 2009) and Klebsiella pneumoniae CBL-1 at concentration of 1500 $\mathrm{mg} / \mathrm{ml}$ (Shamim and Rehman, 2012). The bacteria consortium of metal-tolerance bacteria included
Enterobacteriaceae members, which isolated from the river Yamuna, has been separated as a potency source for generate of electricity (Bhagat et al., 2016). Several of the preceding study showed that isolates Klebsiella pneumoniae, Pseudomonas aeruginosa, and Bacillus cereus were found resistance and prevent cadmium ion (Cd2+) from cell surface (Kafilzadeh et al., 2013). Similarly, Multi metal resistance Alcaligenes xylosoxidans, tolerate range of 2.0 to $4.0 \mathrm{mM}$ for $\mathrm{NiCl} 2$ and $1 \mathrm{mM}$ Cadmium was described by (Sevgi, CORAL, Gizir, \& SANGUN, 2010). Previously studies have reported bacteria resistant to Cadmium community separated from sewage sludge contaminated by cadmium ion $(50 \mu \mathrm{g} / \mathrm{ml})$ and the dominance of bacteria gram-negative with $5.08 \pm 0.88 \%$ Cadmium(Chovanov? et al., 2004).

Table4. Tolerance of the bacterial strains isolated from drainage water to Cadmium expressed as Minimal Inhibitory Concentration (MIC)

\begin{tabular}{ccc}
\hline $\begin{array}{c}\text { Strains } \\
\text { Bacteria } \\
\text { resistant }\end{array}$ & $\begin{array}{c}\mathbf{5 0} \mathbf{~ p p m} \\
\text { after } \mathbf{4 8} \mathbf{~ h}\end{array}$ & $\begin{array}{c}\mathbf{5 0 0} \mathbf{~ p p m} \\
\text { after } \mathbf{4 8 h}\end{array}$ \\
\hline $4(\mathrm{DB}-3)$ & 0.661 & 0.310 \\
$5(\mathrm{DB}-3)$ & 0.709 & 0.124 \\
$6(\mathrm{CB}-3)$ & 0.665 & 0.425 \\
$7(\mathrm{CB}-7)$ & 0.761 & 0.320 \\
$\mathrm{~J}(\mathrm{CB}-5)$ & 0.634 & 0.217 \\
$\mathrm{M}(\mathrm{CB}-3)$ & 0.672 & 0.125 \\
\hline
\end{tabular}

\section{CONCLUSION}

The excess levels of pollution in the water streams leading gathered of heavy metals in the neighboring plants and soil in this area. The entity of heavy metals at low concentrations in the water in addition to agricultural products poses a higher risk to the human and animal health. Such polluted environments pose pressure on microorganism to improve different mechanisms to survive in higher metal concentration. The ability of microbial strains to grow in the entity of heavy metals would be useful in the polluted water treatment. This work demonstrate to be successful in isolating and characterizing a novel heavy metal resistant bacterium, gram negative rod shaped bacteria which resistance to high concentrations of cadmium $(500 \mathrm{mg} / \mathrm{l})$. This isolates mission as an effective adsorbent for bio remediation of cadmium. Further molecular studies are needed for deep identification before using such promising bacteria as tool for the removal this deleterious metal from the contaminated water bodies.

\section{REFERENCES}

Aboulroos, S. and M. Satoh. 2017. Challenges in Exploiting Resources-General Conclusion Irrigated Agriculture in Egypt (pp. 267-283): Springer. 
Allam, M. (2001). Water and Agricultural Lands in Egypt: Past, Present and Future. Academic Library, Cairo.85-86.

AQUASTAT, F. 2012. Freshwater Availability-Precipitation and Internal Renewable Water Resources (IRWR): AQUASTAT online database. Available at: http://www. fao. org/nr/water/aqua stat/data/query/index. html.

Ayers, R. and D. Westcot. 1994. Food, Agriculture Organization of the United Nations (FAO), Water Quality for Agriculture. Irrigation and Drainage, Rome.Paper (29).

Azad, A., A. Nahar, M.Hasan, K. Islam, M.Azim, M. Hossain and R.Kayes 2013. Fermentation of municipal solid wastes by bacterial isolates for production of raw protein degrading proteases. Asian J. of Microbio. Biotechn. and Environ. Sci. 15: 365-374.

Banerjee, S., R.Gothalwal, P. K.Sahu and S. Sao. 2015. Microbial observation in bioaccumulation of heavy metals from the ash dyke of thermal power plants of Chhattisgarh, India. Advances in Bioscience and Biotechnology. 6 (02): 131.

Benidickson, J. 2011. The culture of flushing: A social and legal history of sewage: UBC Press.

Bestawy, E. E., S.Helmy, H. Hussien, M.Fahmy, and R.Amer. 2013. Bioremediation of heavy metalcontaminated effluent using optimized activated sludge bacteria. Applied water sci. 3(1): 181-192.

Bhagat, N., M.Vermani and H. S.Bajwa. 2016. Characterization of heavy metal (cadmium and nickle) tolerant Gram negative enteric bacteria from polluted Yamuna River, Delhi. African J. of Microbiology Research. 10(5): 127-137.

Chovanov?, K., D. Sl?dekov?, V.Kmet , V.Proksova, J.Harichov?, A. Puskarova, and P.Ferianc. 2004. Identification and characterization of eight cadmium resistant bacterial isolates from a cadmium-contaminated sewage sludge. Biologia. 59(6): 817-827.

Coelho, L. M., H. C.Rezende, L. M.Coelho, de P. A.Sousa, D. F.Melo and N. M.Coelho. 2015. Bioremediation of polluted waters using microorganisms Advances in Bioremediation of Wastewater and Polluted Soil: InTech. 3(4):1-22. http://dx.doi.org/10.5772/60770

El-Aziz, Z. K. A., M. H. El-Sayed and A. A. A. El-Ghany. 2016. Microbial Bioremediation of Lead by LeadResistant Pseudomonas chlororaphis Strain Hel-KE'-14 Isolated from Industrial Wastewater. International J. of Pharmaceutical Research \& Allied Sci. 5(4):95-107.

El-Bestawy, E., I.El-Sokkary, H.Hussein and A. F. A.Keela. 2008. Pollution control in pulp and paper industrial effluents using integrated chemical-biological treatment sequences. $J$. of industrial microbiology \& biotechnology.35(11): 1517-1529.

El-Refaey, A.A. 2016 . Role of biofilm on granular wood charcoal in enhancing primary wastewater treatment for irrigation reuse. Alex. Sci. Exch. J. 37: 747 - 758.
Gad, A. A., and R. R. Ali. 2009. Water rationalization in Egypt from the perspective of the virtual water concept. Options Méditerranéennes.(88): 301-310.

Gelmi, M., P.Apostoli, E.Cabibbo, S.Porru, L.Alessio and A.Turano. 1994. Resistance to cadmium salts and metal absorption by different microbial species. Current Microbiology. 29(6): 335-341.

Hettiarachchi, H., and R. Ardakanian. 2016. Safe Use of Wastewater in Agriculture: Good Practice Examples. United Nations University Institute for Integrated Management of Material Fluxes and of Resources (UNUFLORES): Dresden, Germany.

Holt, J. G., N. R.Krieg, P. A.Sneath, J. T.Staley and S. T.Williams. 1994. Bergey's Manual of determinate bacteriology.Williams and Wilkins, Maryland, 9(1):780787

Jamaluddin, H., D. M.Zaki, and Z. Ibrahim. 2012. Isolation of Metal Tolerant Bacteria from Polluted Wastewater. Pertanika J.of Tropical Agricultural Sci. 35(3):647-662.

Jiménez, B. and T. Asano. 2008. Water reclamation and reuse around the world. Water Reuse: an international survey of current practice, issues and needs.20(3):3-142.

Kafilzadeh, F., Y.Moghtaderi and A. R.Jahromi. 2013. Isolation and identification of cadmium-resistant bacteria in Soltan Abad river sediments and determination of tolerance of bacteria through MIC and MBC. European Journal of Experimental Biology.3(5): 268-273.

Kang, J.H. and F.Kondo. 2002. Bisphenol A degradation by bacteria isolated from river water. Archives of environmental contamination and toxicology. 43(3):02650269.

Khalil, N., H.El-Sheshtawy and D.Aman. 2016. Elimination of different heavy metals in contaminated soil using indigenous microorganisms and nanoparticle in the ElRahawy village, Egypt. Egypt. J. Mater. Environ. Sci. 7, 2603-2616.

Kharwar, R. N., P. K.Srivastava and M.Singh. 2017. Role of Rhizospheric Mycobiota in Remediation of Arsenic Metalloids Phytoremediation of Environmental Pollutants. (pp. 137-158). CRC Press.

Khatiwada, P., J.Ahmed, M.Sohag, K.Islam and A.Azad. 2016. Isolation, screening and characterization of cellulase producing bacterial isolates from municipal solid wastes and rice straw wastes. $J$. of Bioprocessing \& Biotechniques. 6:280-285.

Khojastehfar, A., M.Aghaei, M.Gharagozloo and M. Panjehpour. 2015. Cadmium induces reactive oxygen species-dependent apoptosis in MCF-7 human breast cancer cell line. Toxicology mechanisms and methods. 25(1): 48-55.

Marin-Morales, M. A., M. M. Roberto, M. P.Berreta, P.Suares-Rocha and B.de Campos . 2016. Water Reuse: Safety and Applications. 20(6):1-23.

Marzan, L. W., M.Hossain,S. A.Mina, Y.Akter and A. M. A.Chowdhury. 2017. Isolation and biochemical characterization of heavy-metal resistant bacteria from 
tannery effluent in Chittagong city, Bangladesh: Bioremediation viewpoint. The Egyptian J. of Aquatic Research. 43(1): 65-74.

Nasr, M. and H. F.Zahran. 2016. Performance evaluation of agricultural drainage water using modeling and statistical approaches. The Egyptian Journal of Aquatic Research. 42(2):141-148.

Nicolaou, S. A., S. M.Gaida, and E. T.Papoutsakis. 2010. A comparative view of metabolite and substrate stress and tolerance in microbial bioprocessing: from biofuels and chemicals, to biocatalysis and bioremediation. Metabolic engineering. 12(4): 307-331.

Oosterbaan, R. 1999. Impacts of the irrigation improvement project, Egypt, on drainage requirements and water savings. International Institute for Land Reclamation and Improvement (ILRI): Wageningen, www. waterlog. info/pdf/irrimpr. pdf. 3(11):1-52.

Organization, W. H. 2012. UN-Water global annual assessment of sanitation and drinking-water (GLAAS) 2012 report: the challenge of extending and sustaining services.

Qadir, M., D.Wichelns, L.Raschid-Sally, P. G.McCornick, P. Drechsel, A. Bahri and P. Minhas. 2010. The challenges of wastewater irrigation in developing countries. Agricultural Water Management. 97(4): 561-568.

Raja, S., H. M. N.Cheema, S. Babar, A. A.Khan, G.Murtaza and U.Aslam. 2015. Socio-economic background of wastewater irrigation and bioaccumulation of heavy metals in crops and vegetables. Agricultural Water Management. 158: 26-34.
Rajesh, V., A. S. K.Kumar and N. Rajesh. 2014. Biosorption of cadmium using a novel bacterium isolated from an electronic industry effluent. Chemical Engineering J. 235: 176-185.

Rajeshkumar, R., S.Sahu and J. R. Agharwal. 2012. Biosorption of cadmium (II) ions by the cadmium tolerant bacteria isolated from the chemical exposed soil of fireworks industry. J. Pure and Appl Microbio, 6(2): 781787.

Rathnayake, I., M.Megharaj, N. Bolan and R.Naidu. 2010. Tolerance of heavy metals by gram positive soil bacteria.

Rijsberman, F. R. 2006. Water scarcity: fact or fiction? Agricultural water management. 80(1-3): 5-22.

Sato, T., M.Qadir, S. Yamamoto, T. Endo and A.Zahoor. 2013. Global, regional, and country level need for data on wastewater generation, treatment, and use. Agricultural Water Management. 130: 1-13.

Shamim, S. and A.Rehman. 2012. Cadmium resistance and accumulation potential of Klebsiella pneumoniae strain CBL-1 isolated from industrial wastewater. Pakistan Journal Zoology. 44:203-208.

Utgikar, V. P., S. M.Harmon, N.Chaudhary, H. H. Tabak, R. Govind, and J. R. Haines. 2002. Inhibition of sulfate- reducing bacteria by metal sulfide formation in bioremediation of acid mine drainage. Environmental toxicology. 17(1): 40-48.

Yaseen, R.Y., S. M. Abd El-Aziz, D.T. Eissa, and A.M. Abou-Shady. 2018 . Application of biosurfactant producing microorganisms to remediate heavy metal pollution in El-Gabal El-Asfar area. Alex. Sci. Exch. J. 39:17 - 34

Zhai, Q., A.Narbad and W. Chen. 2015. Dietary strategies for the treatment of cadmium and lead toxicity. Nutrients. $7(1): 552-571$. 


\section{الملخص العربي}

\section{عزل وتوصيف جزيئي للبكتيريا المقاومة للكادميوم المعزولة من مياه الصرف الملوثة}

أثجان أبو جبال و ر رانيا عامر وأحمد عبد المجيد وماجدة حيدر مئه

المعادن الثقيلة في معالجة مياه الصرف. ولقد اثبـــت هـــا

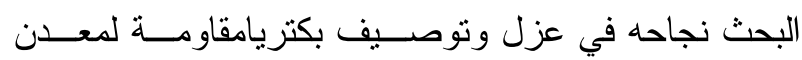

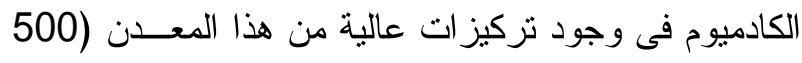

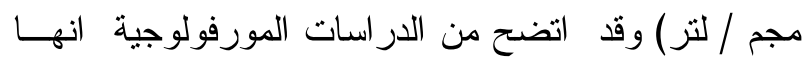

بكتريا عصوية سالبة لصبغة جر ام و وهنالك حاجة الى مزيد

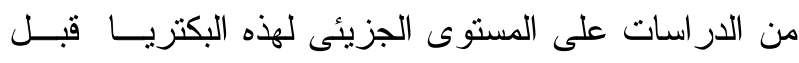

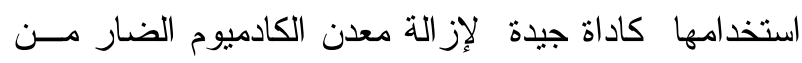

المسطحات المائية الملوثة.
تؤدي زيادة مستويات التلوث في مجاري الميــاه إلــى

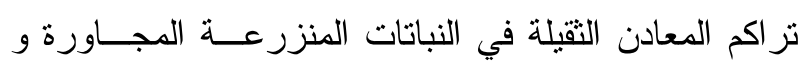

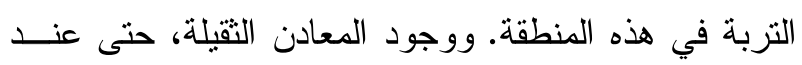

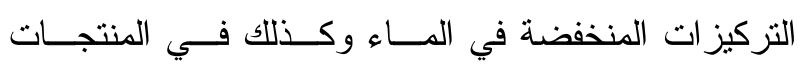
الزر اعية يشكل خطر ا كبير ا على صحة الانسان و الحيوان.

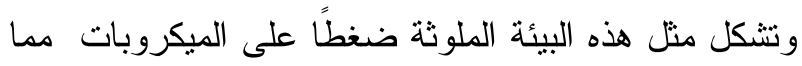

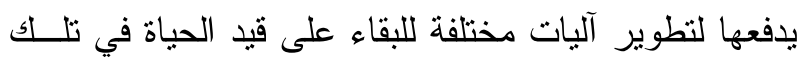

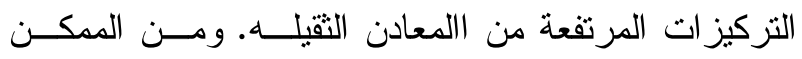

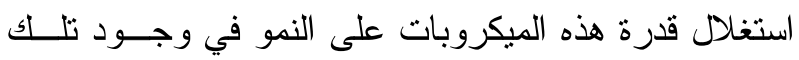

